\title{
Foundations of Human Rights: The Unfinished Business
}

\section{Citation}

Mary Ann Glendon, Foundations of Human Rights: The Unfinished Business, 44 Am. J. Juris. 1 (1999).

\section{Published Version}

http://scholarship.law.nd.edu/ajj/vol44/iss1/1/

\section{Permanent link}

http://nrs.harvard.edu/urn-3:HUL.InstRepos:12990517

\section{Terms of Use}

This article was downloaded from Harvard University's DASH repository, and is made available under the terms and conditions applicable to Other Posted Material, as set forth at http:// nrs.harvard.edu/urn-3:HUL.InstRepos:dash.current.terms-of-use\#LAA

\section{Share Your Story}

The Harvard community has made this article openly available.

Please share how this access benefits you. Submit a story.

Accessibility 


\section{American Journal of Jurisprudence}

Volume 44 | Issue 1

Article 1

1-1-1999

\section{Foundations of Human Rights: The Unfinished Business}

Mary Ann Glendon

Follow this and additional works at: http://scholarship.law.nd.edu/ajj

Part of the Human Rights Law Commons, Jurisprudence Commons, and the Legal History, Theory and Process Commons

\section{Recommended Citation}

Glendon, Mary Ann (1999) "Foundations of Human Rights: The Unfinished Business," American Journal of Jurisprudence: Vol. 44: Iss. 1 , Article 1 .

Available at: http://scholarship.law.nd.edu/ajj/vol44/iss1/1 


\title{
FOUNDATIONS OF HUMAN RIGHTS: THE UNFINISHED BUSINESS
}

\author{
MARY ANN GLENDON
}

Over the two years it took them to draft the 1948 Universal Declaration of Human Rights, the eighteen members of the U.N.'s first Human Rights Commission had surprisingly few discussions of why human beings have rights or why some rights are universal.' After the horrors of two world wars, the need for a minimal common standard of decency seemed evident. One of the first tasks assigned to the new Commission chaired by Eleanor Roosevelt was the preparation of an "international bill of rights." The Commissioners, in haste to complete their work before the deepening Cold War made its acceptance by the General Assembly impossible, left the problem of foundations for another day.

At the Commission's first session in January 1947, China's Peng-chun Chang and Lebanon's Charles Malik did try to initiate a discussion of the premises on which such a document might be based. ${ }^{2}$ Chang was a Confucian philosopher and educator who had done post-graduate work with John Dewey, and Malik was a philosopher of science who had studied with Alfred North Whitehead and Martin Heidegger. Their suggestions precipitated the Commission's first argument. The Yugoslav, French and English delegates began to wrangle over the relation between man and society.

Several other Commissioners became impatient with that sort of discussion. They just wanted to get on with the business at hand. After a time, India's Hansa Mehta broke in. She was one of two women on the Commission, a pioneering human rights activist, a crusader against British colonialism, and an advocate for women's equality. She said, "We are here to affirm faith in fundamental human rights. Whether the human person comes first or the society, I do not think we should discuss that problem now. We do not need to enter into this maze of ideology."

Charles Malik, who had been literally called out of his Beirut classroom and pressed into public service by the government of newly independent

1. For details of the framing of the Universal Declaration, see Mary Ann Glendon, Rights from Wrongs (forthcoming, Random House).

2. Human Rights Commission, First Session, Summary Records (E/CN.4/SR.7 p. 4).

3. Verbatim Record, from The More Important Speeches and Interventions of Charles Malik (Papers of Charles Malik, Library of Congress, Manuscript Division), p. 38. 
Lebanon, had not yet perfected the suave diplomatic style for which he would later become famous. He rebuked Mrs. Mehta as a professor of the old school would chide a student, saying: "Whatever you may say, Madam, must have ideological presuppositions, and no matter how much you may fight shy of them, they are there, and you either hide them or you are brave enough to bring them out in the open and see them and criticize them."4

The Commission's Chair, Eleanor Roosevelt, quickly realized that the group would have to concentrate on specifics if the project was to stay on course. She steered the discussion back to the problem of organizing the group's work schedule. Thereafter, the question of foundations surfaced only sporadically. One such occasion was the presentation of a discussion draft by the Secretariat of the U.N. Human Rights Division. Australia's Colonel Roy Hodgson demanded to know what was the philosophy behind the paper: "What principles did they adopt; what method did they follow?" John Humphrey, the Canadian head of the Human Rights Division, replied that the draft "was based on no philosophy whatsoever." It was, he said, merely a collection from existing constitutions of "every conceivable right which the Drafting Committee might want to discuss."6

At the very end of the drafting process, and without much discussion, the Commissioners did make a statement about the basis of human rights in the Preamble to the 1948 Declaration. The Preamble's opening line recites that "recognition of the inherent dignity and of the equal and inalienable rights of all members of the human family is the foundation of freedom, justice and peace in the world." The word "dignity" appears at so many key points in the Declaration that many scholars believe it represents the Declaration's ultimate value. Louis Henkin puts it this way: "Eschewing - in its quest for universality-explicit reliance on Divine inspiration or on Natural Rights, the Declaration provided the idea of human rights with a universally acceptable foundation, an ur principle, human dignity."7

But inquiring minds must ask what is this "dignity," and what is its basis? Its proximate source is easy to locate. The U.N. Charter professes "faith in freedom and democracy" which, according to the Charter, is grounded in another "faith"- "in the inherent dignity of men and women." That is a good deal of faith for a document that eschews divine inspiration. No wonder we find Nobel laureate Czeslaw Milosz musing ruefully about

4. Ibid., 44. p.5).

5. Human Rights Commission, Drafting Committee, First Session (E/CN.4/AC.1/SR.1

6. Ibid.

7. Louis Henkin, "The Ideals of Human Rights: Ideology and Aspiration, Reality and Prospect," in Human Rights Policy (New York: St. Martin's Press, forthcoming). 
"those beautiful and deeply moving words which pertain to the old repertory of the rights of man and the dignity of the person." Milosz continues, "I wonder at this phenomenon because maybe underneath there is an abyss. After all, these ideas had their foundation in religion, and I am not overoptimistic as to the survival of religion in a scientific-technological civilization. Notions that seemed buried forever have suddenly been resurrected. But how long will they stay afloat if the bottom is taken out?"

Milosz puts the question neatly as only a poet can. Is the universal rights idea merely based on a kind of existential leap of faith? Or does it have some sturdier basis?

Such questions came to the surface when the Universal Declaration celebrated its fiftieth anniversary in 1998 amidst a barrage of attacks upon its aspiration to universality-mainly in the name of cultural relativism. Typically these assaults describe the Declaration as an attempt to universalize a particular "Western" set of ideas and to impose them upon people who were under colonial rule and thus not represented in its creation. The human rights project is dismissed as an instrument of "cultural imperialism" or "neo-colonialism."

An equally common retort is that cultural imperialism is the cry of the world's worst rights violators. That sort of response, however, is obviously inadequate: The allegations of cultural relativism and imperialism could be hypocritical or ideologically motivated, but nevertheless true. I propose therefore to take the accusations seriously.

My conclusions are as follows: (1) The Universal Declaration was an impressively, though imperfectly, multicultural document when it was adopted in 1948. It cannot be dismissed as "Western." (2) The framers of the Declaration did take account of the diversity of cultures by leaving room for a legitimate pluralism in interpreting and implementing its open-ended principles. (3) The danger of human rights imperialism is real, but its source is in the efforts of special interest groups to commandeer human rights for their own purposes, rather than in the Declaration itself. (4) The human rights project will rest on shaky foundations unless and until philosophers and statespersons collaborate on the business that the framers left unfinished.

\section{IS THE UNIVERSAL DEClARATION "WESTERN"?}

Those who label the Universal Declaration "Western" base the claim mainly on two facts: (1) many of the world's peoples, especially those still living under colonial rule, were not represented in the United Nations in

8. Czeslaw Milosz, "The Religious Imagination at 2000," New Perspectives Quarterly, Fall 1997, 32. 
1948, and (2) most of the Declaration's rights first appeared in European and North and South American documents. Those statements are correct, but do they destroy the universality of the Declaration?

Contrary to what is often suggested, the participation by developing countries in the framing of the Declaration was by no means negligible. ${ }^{9}$ At the U.N.'s founding conference in San Francisco in 1945, it was chiefly the smaller or less-developed nations who were responsible for the prominent position of human rights in the U.N. Charter. Within the eighteen-member Human Rights Commission, China's Peng-chun Chang, Lebanon's Charles Malik, the Philippines' Carlos Romulo, and Chile's Hernàn Santa Cruz were among the most influential and active members. It is sometimes said that the educational backgrounds or professional experiences of widely traveled men like Chang and Malik "westernized" them, but their performance in the Human Rights Commission suggests something rather different. Not only did each contribute significant insights from his own culture, but each possessed an exceptional ability to understand other cultures, and to "translate" concepts from one frame of reference to another. Those skills, which can hardly be acquired without substantial exposure to traditions other than one's own, are indispensable for effective cross-cultural collaboration and were key to the adoption of the Declaration without a single dissenting vote in 1948.

The Declaration itself was based on extensive comparative study. The first draft, prepared by the U.N. Secretariat, was accompanied by a 408-page document showing the relationship of each article to provisions of the world's existing and proposed constitutions and declarations. When the Human Rights Commission's second draft was submitted to U.N. members for comment, responses were received from a group of nations that included Brazil, Egypt, India, Mexico, and Pakistan, South Africa, Sweden, and the United States.

Among the fifty-eight Member States represented on the U.N. General Assembly's committee which reviewed the near-final draft in the fall of 1948, there was even greater cultural and ideological diversity. This Committee on Social, Cultural and Humanitarian Affairs (known as the Third Committee) was chaired by Charles Malik. It included six members from Asia, four from the African continent (Egypt, Ethiopia, Liberia, and South Africa), plus the large Latin American contingent. Six of the "European" members belonged to the Communist bloc; Islamic culture was strong in eleven; and four had large Buddhist populations. Over the course of more than a hundred meetings, the members of this large committee went

9. See also Philip Alston, "The Universal Declaration at 35: Western and Passé or Alive and Universal?," International Commission of Jurists Review 30 (1983) 60, 61; and Johannes Morsink, The Universal Declaration of Human Rights: Origins, Drafting, and Intent (Philadelphia: University of Pennsylvania Press, 1999), especially the concise summary of the drafting process in pp. 1-12. 
over every word of the draft. Each country's representatives were given, and most of them enthusiastically seized, the opportunity to participate.

At the end of this process, Charles Malik could justly say of the Universal Declaration that "All effective cultures in the world had a creative hand in the shaping of the document...." As Malik put it, "The genesis of each article, and each part of each article, was a dynamic process in which many minds, interests, backgrounds, legal systems and ideological persuasions played their respective determining roles." 10

It was, of course, true that much of the world's population was not represented in the U.N. in 1948. Large parts of Africa and Asia in particular remained under colonial rule. The defeated Axis powers, Japan, Germany, and their allies, were excluded. On the other hand, subsequent actions by the non-represented countries suggest that cultural "diversity" has been greatly exaggerated where basic human goods are concerned. Most new nations adopted constitutions resembling the Universal Declaration as soon as they gained independence. Later, nearly all of these countries ratified the two 1966 Covenants based on the Declaration. In 1993, virtually all countries in the world participated in the adoption of the Vienna Human Rights Declaration, which reaffirms the Universal Declaration. It is hard to dismiss this overwhelming endorsement of the principles of the Declaration as a mere vestige of the colonial mentality.

It is unlikely that any other political document in history has ever drawn from such diverse sources, or received the same worldwide, sustained consideration and scrutiny as the Declaration underwent over its two years of preparation. Despite all the wrangling that occurred over specifics, moreover, there was remarkably little disagreement regarding its basic substance. At every stage, even the Communist bloc, South Africa, and Saudi Arabia voted in favor of most of the articles when they were taken up one by one. The biggest battles were political, occasioned by Soviet concerns to protect their national sovereignty.

But what of the second objection mentioned above - the fact that several key ideas in the Declaration were initially described as rights in early modern Europe? On this point, the findings of a UNESCO philosophers' committee that included Jacques Maritain and University of Chicago philosopher Richard McKeon are instructive. After surveying leading philosophers and religious thinkers the world over, the UNESCO group discovered to its surprise that a few basic practical concepts of humane conduct were so widely shared that they "may be viewed as implicit in man's nature as a member of society." "Freedom, dignity, tolerance, and

10. Charles Malik, "Introduction," in O. Frederick Nolde, Free and Equal: Human Rights in Ecumenical Perspective (Geneva: World Council of Churches, 1968), 12.

11. Richard P. McKeon, "The Philosophic Bases and Material Circumstances of the Rights of Man," in Human Rights: Comments and Interpretations(New York: Columbia University Press, 1949), 45. 
neighborliness, they found, were highly prized in many cultural and religious traditions.

Nevertheless, the elaboration of these concepts as "rights" was a relatively modern, and European, phenomenon. So, does that give human rights a genetic taint that prevents them from being "universal"? Surely, their origin ought not to be decisive. The question should be not who had the idea first, but whether the idea is a good one; not where the idea was born, but whether it is conducive to human flourishing. Moreover, if a legal-political idea originated in one country but was widely adopted and internalized elsewhere, for how long and in what sense does it still "belong" to its country of origin? Do not all vibrant, living cultures constantly borrow from one another?

Consider the civil-law tradition which originated in ancient Rome. That tradition was in 1948, and remains, the most widely distributed legal tradition in the world. ${ }^{12}$ The form and style of the Declaration gives it a familial resemblance, not only to rights declarations in many continental European constitutions, but to the constitutions and charters that had appeared or were soon to appear in many Latin American, African and Asian countries. Does that make all these instruments Roman? The French Civil Code of 1804 was widely copied by newly independent peoples in Latin America who admired its clarity and were inspired by its consolidation of a Revolution which had abolished the old unequal statuses of feudalism. Does that make the law of all those countries French?

And what does the term "Western" mean anyway, if it is more than an epithet? The majority of the U.N.'s membership in 1948, perhaps as many as thirty-seven countries, might have been described as "Western" in the sense of being influenced by Judeo-Christian traditions and Enlightenment thought. But how much sense does it make to lump together under a single label a group that comprises Latin Americans, North Americans, East and West Europeans, Australians and New Zealanders? By the same token, such broad concepts as "Asian" or "Islamic" values are not very informative, given the great variety within traditions. ${ }^{13}$ As the Chinese member of the first Human Rights Commission, P. C. Chang, observed long ago, "Culturally, there are many 'Easts' and many 'Wests'; and they are by no means all necessarily irreconcilable."14

12. See, Mary Ann Glendon, Michael Gordon, and Christopher Osakwe, Comparative Legal Traditions, 2d ed. (St. Paul, Minn.: West, 1994), 58-62.

13. See Amartya Sen's illuminating reflections on universality and pluralism, in "Our Culture, Their Culture," The New Republic, April 1, 1996, 27.

14. P. C. Chang, China at the Crossroads: The Chinese Situation in Perspective (London: Evans, 1936), 124-25. 


\section{How CAN There be Universal Rights In Diverse Cultures?}

Let us now turn to a more sophisticated version of the cultural-relativism critique. Assume that the UNESCO philosophers were right that a few basic norms of decent human behavior are very widely shared. Even if that is so at a general level, different nations and cultures attach quite different weights to these norms. Moreover, different political and economic conditions affect each nation's ability to bring human rights principles to life. That being so, what sense does it make to speak of universality?

That version of the cultural-relativism critique rests on a false premise shared by many rights activists and rights skeptics alike. It is the assumption that universal principles must be implemented in the same way everywhere. The Declaration's framers, however, never envisioned that its "common standard of achievement" would or should produce completely uniform practices. ${ }^{15}$ P. C. Chang stressed that point in his 9 December 1948 speech to the General Assembly urging adoption of the Declaration. He deplored that colonial powers had tried to impose on other peoples a standardized way of thinking and a single way of life. That sort of uniformity could only be achieved, he said, by force or at the expense of truth. It could never last. ${ }^{16}$ Chang and his colleagues on the Drafting Committee expected the Declaration's rights would be inculturated in various ways, and that over time the corpus of human rights would be enriched by these varied experiences.

The framers of the Universal Declaration also knew it was neither possible nor desirable for the Declaration to be frozen in time. They never claimed to have produced the last word on human rights. They expected that new rights would emerge in the future as they had in the past, and that old rights might be reformulated. That did not mean, however, that interpretation was up for grabs. They tried to provide the Declaration with safe passage through such transitions by giving it an interpretive matrix: freedom and solidarity, linked to a thick concept of personhood, and grounded in dignity.

The framers' approach was remembered by at least one distinguished international lawyer on the document's thirty-fifth anniversary in 1983. Philip Alston wrote on that occasion, "The Declaration does not purport to offer a single unified conception of the world as it should be nor does it purport to offer some sort of comprehensive recipe for the attainment of an ideal world. Its purpose is rather the more modest one of proclaiming a set of values which are capable of giving some guidance to modern society in

15. Jacques Maritain, "Introduction" in Human Rights: Comments and Interpretations, UNESCO ed. (New York: Wingate, 1949), 16.

16. P. C. Chang's speech may be found in U.N. General Assembly, 182d Plenary Session, December 10, 1948, Summary Records, p. 895. 
choosing among a wide range of alternative policy options."17 By the 1970s, however, the original understanding of the Declaration was largely forgotten. And what oblivion had not erased, opportunism was eroding. The abstentions by South Africa and Saudi Arabia from the final vote approving the Declaration had been early warnings of more trouble ahead. South Africa had objected, among other things, to the word "dignity," apparently fearing its implications for the apartheid system it was then constructing. And Saudi Arabia had claimed that some of the so-called universal rights, particularly the right to change one's religion, were really just "Western" ideas. In 1948, those were isolated claims. But no sooner was the Declaration adopted than the Cold War antagonists pulled apart and politicized its provisions. That set the stage for further mischief. In 1955, the charge that some rights represented "Western" neo-colonialism resurfaced with particular vehemence at the Bandung conference, where the "nonaligned" nations found unity of a sort in shared resentment of the dominance of a few rich and powerful countries in world affairs.

\section{THE DECONSTRUCTION DERBY}

Over the 1960s and 1970s, the Declaration's framers, one by one, were departing from the world stage. The U.N. grew into an elaborate bureaucracy with more than 50,000 employees. Its specialized agencies become closely intertwined with the nongovernmental organizations that proliferated as the international human rights movement gained ground in the 1960s and 1970s. That movement in turn was deeply affected by the ideas about rights that predominated in the United States in those days. ${ }^{18}$ The movement, like the Declaration itself, attracted many persons and groups who were more interested in harnessing its moral authority for their own ends than in furthering its original purposes.

Another important development, set in motion by the Cold War antagonists, was the nearly universal habit of reading the Declaration in the way that Americans read the Bill of Rights, that is, as a string of essentially separate guarantees. Its dignity-based language of rights began to be displaced by the more simplistic kinds of rights talk that were then making great inroads on political discourse in the United States. Several features of that new, hyper-individualistic dialect had the potential to wreak havoc with the Declaration: rights envisioned without individual or social responsibilities; one's favorite rights touted as absolute with others ignored; the rightsbearer imagined as radically autonomous and self-sufficient; the trivialization of core freedoms by special interests posing as new rights. ${ }^{19}$

17. Philip Alston, "The Universal Declaration at 35," 60, 69.

18. See generally, Mary Ann Glendon, Rights Talk: The Impoverishment of Political Discourse (New York: Free Press, 1991) (especially Chapter 6); Anthony Lester, "The Overseas Trade in the American Bill of Rights," Columbia Law Review 88 (1988) 537.

19. See generally, Glendon, Rights Talk. On the need for care in accepting new rights, 
Thus, ironically, the charge of cultural imperialism has more credibility than it had in 1948. The global spread of hyper-libertarian, radically individualistic, sound-bite rights ideas has rendered the contemporary international human rights project more vulnerable to the label of "Western" than the Declaration ever was. Launched as a commitment by the nations to compete in advancing human freedom and dignity, the Declaration is now in danger of becoming what its critics have always accused it of being-an instrument of neo-colonialism!

For decades, the seamlessness of the Declaration has been ignored by its professed supporters as well as by its attackers. By isolating each part from its place in the overall design, the now-common misreading of the Declaration promotes misunderstanding and facilitates misuse. Nations and interest groups ignore the provisions they find inconvenient and treat others as trumps. A major casualty has been the Declaration's insistence on the links between freedom and solidarity, just at a time when affluent nations seem increasingly to be washing their hands of poor countries and peoples.

For examples of deconstruction in operation, one could do no better than to eavesdrop on the rights babble of the big U.N. conferences of the 1990s. At first glance, the U.N. might seem to be an unlikely forum for the pursuit of law reform. But its agencies and conferences have attracted numerous special interest groups whose agendas have trouble passing muster in ordinary domestic political processes. Over the years, lobbyists of various sorts have acquired considerable influence in the U.N. bureaucracy, whose processes are even less transparent than those of U.S. administrative agencies.

Thus was the stage set for the U.N. and its conferences to become offshore manufacturing sites where the least popular (or least avowable) ideas of special interest groups could be converted into "international norms." These norms, though technically lacking the status of fundamental rights, could then be portrayed at home as universal standards, and imposed on poor countries as conditions for the receipt of aid.

At the U.N.'s 1995 Women's Conference in Beijing, for example, strenuous efforts were made to advance a new human rights paradigm-mainly by representatives from affluent countries. In her speech to a plenary session on the second day of the conference, U.S. First Lady Hillary Rodham Clinton gave high visibility to a misleading slogan. "If there is one message that echoes forth from this conference," she asserted, "it is that human rights are women's rights, and women's rights are human rights."20 The statement was half true, but only half true. Human rights do belong to everyone. But not every right that has been granted to women

see Philip Alston, “Conjuring up New Rights: A Proposal for Quality Control," American Journal of International Law 78 (1984) 607.

20. Steven Mufson, "First Lady Critical of China, Others on Women's Rights," Washington Post, September 6, 1995, p. Al. 
by a particular nation-state has gained the status of a human right. The slogan was mainly aimed at universalizing extreme, American-style abortion rights in a world where few countries, if any, go as far as the United States and China in permitting abortions of healthy, viable unborn children.

That there might be some such demolition derby in the Declaration's future was foreseen long ago by Richard McKeon. McKeon realized what every lawyer knows: practical agreements such as those reached by the U.N. member states in 1948 are achieved only at the price of a certain ambiguity. The framers knew that the same generality that made agreement possible, rendered the document vulnerable to misunderstanding and manipulation. In his UNESCO report, McKeon pointed out that different understandings of the meanings of rights usually reflect divergent concepts of man and of society which in turn cause the persons who hold those understandings to have different views of reality. Thus, he predicted that "difficulties will be discovered in the suspicions, suggested by these differences, concerning the tangential uses that might be made of a declaration of human rights for the purpose of advancing special interests."21 That was a philosopher's way of saying, "Watch out, this whole enterprise could be hijacked!"

In sum, the human rights project, launched as a multicultural commitment to compete in advancing freedom and dignity, is now in danger of becoming what its enemies and critics have always accused it of being - an instrument of "Western" cultural imperialism.

That irony did not escape the attention of Calcutta-born, Cambridge economist, Amartya Sen. In 1994, just before the U.N.'s Cairo Conference on Population and Development, Sen warned in the New York Review of Books that the developed nations were exhibiting a dangerous tendency to approach population issues with a mentality that "treats the people involved not as reasonable beings, allies faced with a common problem, but as impulsive and uncontrolled sources of great social harm, in need of strong discipline."22 Sen, who won the Nobel Prize for his works on inequality and world hunger, charged that international policy makers, by giving priority to "family planning arrangements in the Third World countries over other commitments such as education and health care, produce negative effects on people's well-being and reduce their freedoms."23 In short, the whole range of human rights of poor people is at risk when special interests are dressed up as universal rights.

21. Richard McKeon, "The Philosophic Bases and Material Circumstances of the Rights of Man," in Human Rights: Comments and Interpretations (New York: Columbia University Press, 1949), 35, 36.

22. Amartya Sen, "Population: Delusion and Reality," New York Review of Books, September 22, 1994, 62.

23. Ibid., 71; see also, Reed Boland, "The Environment, Population, and Women's Human Rights," Environmental Law 27 (1997) 1137. 
The good news is that as the U.N. enters a period of austerity, the era of big conferences like Cairo and Beijing is probably drawing to a close. The bad news is that the same economic pressures that are putting a damper on huge international gatherings, however, may aggravate the danger of capture of U.N. agencies by well-financed special interests. A case in point is CNN founder Ted Turner's \$1 billion "gift" to the U.N. announced in the fall of 1997. Many who look to the U.N. for leadership in humanitarian aid were overjoyed when Mr. Turner announced that his donation was to help "the poorest of the poor."24 Paid out in installments of $\$ 100$ million a year for ten years, this infusion of funds would have ranked behind the annual contributions of only the U.S., Japan, and Germany.

The news seemed too good to be true. It was. It soon appeared that the U.N. would not have control over the funds. Rather, its agencies would be required to submit proposals for approval by a foundation headed by a man Mr. Turner chose because "he thinks as I do."25 The man designated to have the chief say in allocating the Turner millions is former U.S. State Department official Timothy Wirth, who spearheaded the aggressive U.S. population control agenda at the 1994 Cairo conference. Wirth has been so zealous in advocating population control that he has even praised China, with its coercive one-child-per-family policy, for its "very, very effective high-investment family planning." ${ }^{26}$ As for Mr. Turner, he told a California audience in 1998 that in the post-Cold War world, "The real threat is no longer an army marching on us, it's people infiltrating us, you know, people that are starving."27

As its details have unfolded, Mr. Turner's gesture looks less like a gift and more like a take-over bid aimed at U.N. agencies with privileged access to vulnerable populations. The next few years are thus likely to be a time of testing for the U.N. if its prestige and organizational resources are not to be, literally, for sale.

As memories fade about why the nations of the world determined after World War II to affirm certain basic rights as universal, efforts to deconstruct the Universal Declaration and remake it nearer to the heart's desire of this or that special interest group will continue. Whether the relatively rich and complex vision of human rights in the Universal Declaration can withstand the combined stresses of aggressive lobbying, heightened national and ethnic assertiveness, and the powerful, ambiguous forces of globalization, is impossible to foresee. Not only U.N. agencies,

24. Betsy Pisik, "Gift Keeps on Giving," Washington Times, January 19, 1998, p. Al.

25. Barbara Crossette, "Turner Picks State Dept. Official to Allocate UN Fund," International Herald Tribune, November 21, 1997, 4; Colin Woodard, "Ted Turner Gift Poised to Boost UN," Christian Science Monitor, April 22, 1998, 1.

26. Quoted in Jeffrey Gedmin, "Clinton's Touchy-Feely Foreign Policy," Weekly Standard, May 13, 1996, 19, 22.

27. Ann Bardach, "Turner in 2000?," New Yorker, November 23, 1998, 36, 37. 
but the governments of several liberal democracies have become implicated in breaking down the connections among its indivisible rights and deconstructing its core principle, human dignity.

\section{The Challenge of Human Rights}

The contest for control of the meaning of the Declaration forcefully reminds us that the framers of the Universal Declaration left the human rights movement with a problem. As John Paul II put it in his Address to the Vatican Diplomatic Corps in January 1989, "[T] 1948 Declaration does not contain the anthropological and moral bases for the human rights that it proclaims." How, then, can one handle the problem of reconciling tensions among the various rights, or the related problem of integrating new rights from time to time?

Those problems are serious, and have led some thoughtful persons to conclude that the Declaration is hopelessly incoherent. The late Michel Villey, for example, maintained that, "Each of the so-called human rights is the negation of other human rights, and when practiced separately generates injustices. ${ }^{, 28}$ Alasdair MacIntyre argues that different rights, borrowed from different traditions, often rest on different, and incommensurable, moral premises. ${ }^{29}$

These problems were not overlooked by Maritain and his colleagues. Maritain noted that, "Where difficulties and arguments begin is in the determination of the scale of values governing the exercise and concrete integration of these various rights." ${ }^{30}$ The Declaration, he went on, would need some "ultimate value whereon those rights depend and in terms of which they are integrated by mutual limitations." That value, explicitly set forth in the Declaration, is human dignity. But as time went on, it has become painfully apparent that dignity possesses no more immunity to hijacking than any other concept. One need only think of current defenses of active euthanasia in terms of "the right to die with dignity." (There is no end, it seems, of pseudo-rights that the stronger are eager to confer upon the weaker whether the latter are willing or not.)

The shift from nature to dignity in modern thinking about the foundations of human rights thus entails a host of difficulties. The common secular understandings are that human beings have dignity because they are autonomous beings capable of making choices (Kant), or because of the sense of empathy that most human beings feel for other sentient creatures (Rousseau). But the former understanding has alarming implications for

28. Michel Villey, Le droit et les droits de l'homme (Paris: Presses Universitaires de France, 1983), 13.

29. Alasdair Macintyre, After Virtue, $2 \mathrm{~d}$ ed. (Notre Dame, Ind.: University of Notre Dame Press, 1981).

30. Jacques Maritain, "Introduction" in Human Rights: Comments and Interpretations, UNESCO ed. (London \& New York: Wingate, 1949), 9, 15-16. 
persons of diminished capacity, and the latter places all morality on the fragile basis of a transient feeling. Most believers, for their part, would say that dignity is grounded in the fact that human beings are made in the image and likeness of God, but that proposition is unintelligible to nonbelievers.

Moreover, the path from dignity to rights is not clear and straight, even for believers. Brian Benestad has pointed out that the term "dignity of the human person" has two different connotations in Christian teaching-" "[it] is both a given and an achievement or an end to be gradually realized." ${ }^{31}$ The Catholic Catechism, he notes, begins its discussion of morality with this quotation from Pope Leo the Great: "Christian, recognize your dignity, and now that you share in God's own nature, do not return by sin to your former base condition." But if dignity is a quality to be achieved by strenuous effort to overcome sin and practice virtue, then it is not altogether clear that the dignity of the rights claimant is an adequate basis for human rights. Not every rights claimant, obviously, has made strenuous effort to overcome sin. From a Christian point of view, the resolution of this dilemma may be that human rights are grounded in the obligation of everyone to perfect one's own dignity which in turn obliges one to respect the "given" spark of dignity of others whatever they may have done with it. In other words, it may be our own quest for dignity (individually and as a society) that requires us to refrain from inflicting cruel punishments on criminals, or from terminating the lives of the unborn and others whose faculties are undeveloped or dormant.

In that light, the drafters of the U.N. Charter were prudent to say that human rights rest upon a "faith" in human dignity. It would be a mistake, however, to leap from that proposition to the notion that this faith is merely an act of will, an arbitrary choice. All in all, one may say of "dignity" in the Universal Declaration what Abraham Lincoln once said about "equality" in the Declaration of Independence: it is a hard nut to crack. The framers of the Universal Declaration were far from naive about the difficulties that lay ahead. That is evident from many statements in which they acknowledged the priority of culture over law. Though Maritain was not, strictly speaking, a framer, he said it best. Whether the music played on the Declaration's thirty strings will be "in tune with, or harmful to, human dignity," he wrote, will depend primarily on the extent to which a "culture of human dignity develops." 32

If Maritain, Eleanor Roosevelt, Charles Malik, René Cassin and others who held this view were right, then a great challenge faces the world's religions, for religion is at the heart of culture. Ultimately it will be up to the religions to demonstrate whether they are capable of motivating their

31. Brian Benestad, “What Do Catholics Know about Catholic Social Thought?" in Festschriff for George Kelly (Christendom Press, forthcoming).

32. Jacques Maritain, "Introduction" at $\mathbf{1 6 .}$ 
followers to fulfill their own calling to perfect their own dignity, and in so doing to respect the dignity of fellow members of the human family. ${ }^{33}$

33. Giorgio Filibeck, "Universal Religions and the Universality of Human Rights," Presentation at the Harvard Law School World Alumni Congress Panel on "Religion and Human Rights," held at the Islamic Center of Rome, Italy, June 11, 1998. 